\title{
Article \\ Chemical Characterization of Olive Pomace in the Northern Region of Jordan
}

\author{
Mohammed Wedyan *, Bilal Abu Hanieh and Ahmed Al Harahsheh \\ Biological Sciences and Biotechnology Department, The Hashemite University, Al Zarka O Box 330127, \\ Jordan; new_be_86@yahoo.com (B.A.H.); ahmad.jamall@yahoo.com (A.A.H.) \\ * Correspondence: mwedyan@hu.edu.jo
}

\begin{abstract}
In this study, the olive pomace was considered because of its importance in the environment. So, this study carried out to estimate the total nitrogen content and the fatty acids profile of olive pomace. The olive pomace samples were collected from Irbid, Jarash, Ajloun and Mafraq during the harvesting season 2014 to study the biochemical characteristics of fatty acid composition and the total nitrogen (TN) content. The total nitrogen content was determined by standard Kjeldahl method and the fatty acid profile was detected by gas chromatography (GC). The results show that the total nitrogen content ranged from $(0.39 \pm 0.0)$ to $(0.62 \pm 0.02)$ with statistically significant difference suggesting that the composition of matrices and their percentage may be responsible for composition of amendments. The calculated total protein percentage ranged between $(2.43 \pm 0.00)$ to $(3.87 \pm 0.17)$. Also, 13 different fatty acids were quantitatively profiled and quantitated. Oleic acid (C 18:1) was found to be the highest percentage of all other fatty acids and ranged between (59.03\%) and (63.81\%), moreover the C 18:1/C 18:2 (oil quality) was calculated and C.V\% showed variation meaning that nutritional implication could affect the oxidative stability of oils. In conclusion, OP by-product could give a sustainable and alternative-cheap source for fertilizers, pharmaceutical industries, cosmetics and other industries.
\end{abstract}

Keywords: olive pomace oil; fatty acid profile; total nitrogen content; total protein; olive pomace; biochemical characterization

\section{Introduction}

For many reasons, plant by-products has been interested by the use of their components and for the decrease of environmental problems related with by-product degradation. So, the extraction of proteins from the defatted sunflower and rapeseed meals is an example for obtaining protein isolates [Saeed, et. al, 1988; El Nockrashy, et. al, 1977] or even high added-value protein hydrolysates [Vioque, et. al. 1999; Lahl and Braun, 1994]. Conversely, olive pomace is preferred due to its high amount produced and low price, could be a cheap source of nutritional stuff or proteins for use in the food industry. In fact, all previous studies have been recommended that olive pomace could be used for animal feeding after increasing protein content to 15-18\% [Fedeli, 1996]. The pomace as by-product is characterized by high-fiber content, $\simeq(70 \%)$, and low-protein amount, $\simeq(6 \%)$. In addition, the yield of protein extraction is low, around $6.9 \%$ of total proteins, mainly because these proteins were highly denatured and/or combined with fibers and other components such as tannins [Valiente et. al., 1995; Kumar and Tannins, 1984]. The data regarding the biochemical and chemical composition of olive pomace (OP) are insufficient to fulfill the need and sometimes differ because of the use of different kind of cultivar and may the climate indifference affect this information. In general as stated above the OP has high content of fiber and relatively low of nitrogen amounts.

Olive oil is a strategic product in Jordan, while OP is the main by-product of olive industry; and it is a major environmental concern for all the olive-producing countries. The main olive varieties are Nabali (baladi and mohassan) and Rasie, both indigenous, which appearance to have been cultivated in the area for long periods of time. Another local variety called Souri, 
cultivated in the area of Ajloun and Jerash, has very good and differentiated organoleptic features according to local experts. Many other varieties, most of them of Italian origin, are also grown in Jordan. (http://www.zaitt.com/about-zaitt). Because of the gradually increase of global population, researches on the waste-management issues of OP has been vigorous over the last decade, as results in higher food consumption and increased demand for processed food, meat, dairy and fish [Charles, et al., 2010]. Previous studies show that OP can be used as additional constituent of fish oil in fish nourish improving its cardio protective possessions [Nasopoulou et al., 2011]. The use of OP in agriculture and aquaculture carries improvements at different heights and these must be assessed in terms of water-efficiency, enhanced nutritional value of the last animal and fish foods and last food and also maintainable production of animal and fish foods [Nasopoulou et al., 2011 ; Nasopoulou and Zabetakis, 2013]. At the same time the biggest challenge for food industries and scientists is to develop environmentally maintainable processes of food production reinsuring food security and suppressing environmental pollution. To overcome this problem, food chain managements must find an alternative method that required combines resource management with the crucial aim that the final product can satisfy the human population's needs in terms of quantity and physical properties (i.e. odor, taste and aftertaste) and nutritional value. OP has also been proposed as a substitute source of nutrients for domestic animal feeding [Sansoucy, 1985], while the advantages of using agricultural by-products such as OP in livestock feeding are not only on minimizing environmental pollution, but also decreasing dependency on extremely expensive ingredients such as grains and fibers [Gasser, et. al., $1995]$.

As known OP is one of two main by-products of the olive oil extraction industry and the other being the olive mill wastewater (OMWW) [Brunetti, et. al., 2005; Cardoso, et. al. 2002]. Thus OP is a natural agricultural by-product of olive oil production. A more efficient and environmentally friendly centrifugation process - merges OP with OMWW to produce a single by-product named olive mill waste (OMW), containing higher moisture and lower oil content compared to the traditional threephase centrifugal technology by-product [Alburquerque, et. al., 2004].The world annual production of olive oil is estimated to be 2.9 million tons with some [Di Giovacchino, 1996] million tons resulted in production of OMW being produced annually [Roig, et., al. 2006]. In Mediterranean countries olive orchards has been a major part of the agricultural sector of these countries for many decades. Every $100 \mathrm{~kg}$ of olives resulted in $35 \mathrm{~kg}$ of OP as a by-product; it could be suggested that the production of OMW and OP are viable and the availability of OP for use in any type of feed production. The estimated price of OP is $0.05-0.1 \mathrm{JD} / \mathrm{kg}$. OP's oil and water content depends on the process applied and on the operating conditions; it contains about $8 \%$ oil and the recovery of oil is carried out by extraction with solvent. In order to make the oil eatable, OP has to be de-acidified, bleached and deodorized [Di Giovacchino, 1996]. After refining, refined OP oil is mixed with virgin olive oil and is thus eligible for the commercial class of OP oil as defined by [Official Journal of European Communities. Regulation EEC No 356/92, 1992].

This is the first time we are going to characterize the fatty acid profile of Olive pomace in Jordan. So, this study aimed to, firstly, estimate the content of total nitrogen in the olive pomace collected from north Jordan, and determine the protein concentration in the olive pomace. Finally, assess the fatty acid profile in the olive pomace.

\section{Materials and Methods}

\section{Sample collection}

All samples (200 samples) of olive pomace from three phases centrifugal mills used in this study were obtained from four provinces in the region of the northern of Jordan (Irbid, Jarash, Ajloun and 
Al-mafraq) between November and December harvest season 2014. Several samples from each sampling sites, all samples are presented Fig.1, the pomace was collected in a closed plastic container, and all samples were immediately maintained at $4^{\circ} \mathrm{C}$ so prevent biodegradation

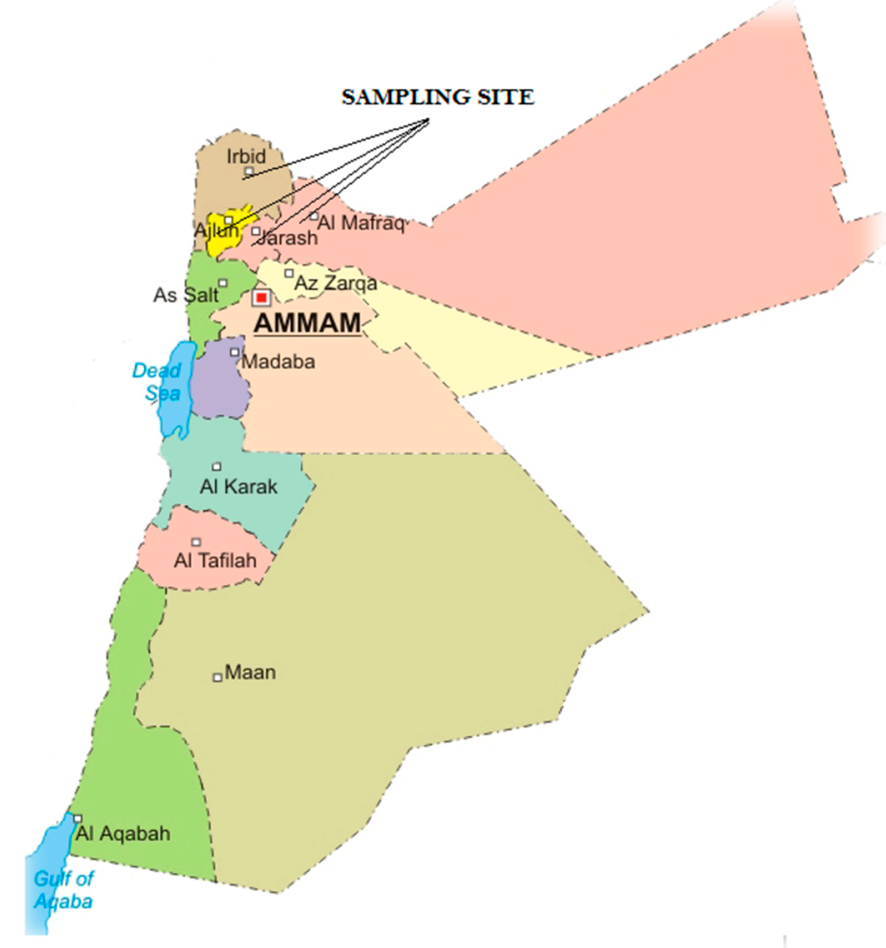

Figure 1: Sampling site。

\section{Total nitrogen}

Nitrogen content was determined by a Kjeldahl procedure [Williams, S., ed. 1984. Official methods of analysis of the Association of Official Analytical Chemists, Arlington, VA]

\section{Protein Content}

The protein content was derived from the $\mathrm{N}$ content found on dry biomass, using a conversion factor of $6,25$.

\section{Lipid Extraction from Olive Pomace}

Soxhlet extractions were performed: $2 \mathrm{~g}$ of pomace were placed in a packet made in filter paper, which was placed in a Soxhlet apparatus. The extraction was made using hexane under heating and lasted 4 hours. The hexane was then evaporated from the resulting oil using nitrogen.

The extraction and determination of total lipid (TL) of OP of samples was performed using method according to AOAC No. 905.02 [AOAC, 2000]. The analyses were conducted in triplicate.

Methyl esters of fatty acids (FAME) were prepared by transmethylation of fat samples using a mixture of concentrated $\mathrm{H} 2 \mathrm{SO} 4$ (95\%) and methanol according to AOCS Official Method Ce 2-66 [AOCS, 2000]. Fatty acids composition was determined by gas chromatography (GC), using Shimadzu, model GC-2010, Inc., Koyoto, Japan with split/splitless injector, FID detector, Rtx 2330 Restek capillary column with a stationary phase of high polarity: $100 \mathrm{~m}$ in length, $0.25 \mathrm{~mm}$ in diameter, with fi $\operatorname{lm}$ thickness of $0.1 \mu \mathrm{m}$, at column temperature: initial $120^{\circ} \mathrm{C}$, fi nal $210^{\circ} \mathrm{C}$, and time of analysis: $120 \mathrm{~min}$.

The standard of fat CRM 164 (Community Bureau of Reference, EU, and Brussels, Belgium) and Supelco 37 No: 47885-U standard (Sigma Aldrich) were applied for fatty acids identification. The results were expressed as percentage of the sum of resolved methyl esters. 
The statistical analysis was conducted in order to verify the significance of differences in contents of individual fatty acids in pomace samples from different area using one-way analysis of variance (ANOVA) and Tukey's test. The calculations were performed at a significance level of $\mathrm{p}<0.05$.

\section{RESULTS AND DISCUSSION}

\section{Nitrogen and Protein}

Results showed the percentage of nitrogen content and protein content of the olive pomace that collected from different locations was ranged from $(0.39 \pm 0.0-0.62 \pm 0.02),(2.43 \% \pm 0.00-$ $3.87 \pm 0.17) \%$ respectively. Ajloun sample shows the highest amount of nitrogen ( $P \leq 0.05$ ) compared to other samples collected from each of Irbid, Jarash, Mafraq (fig 2).

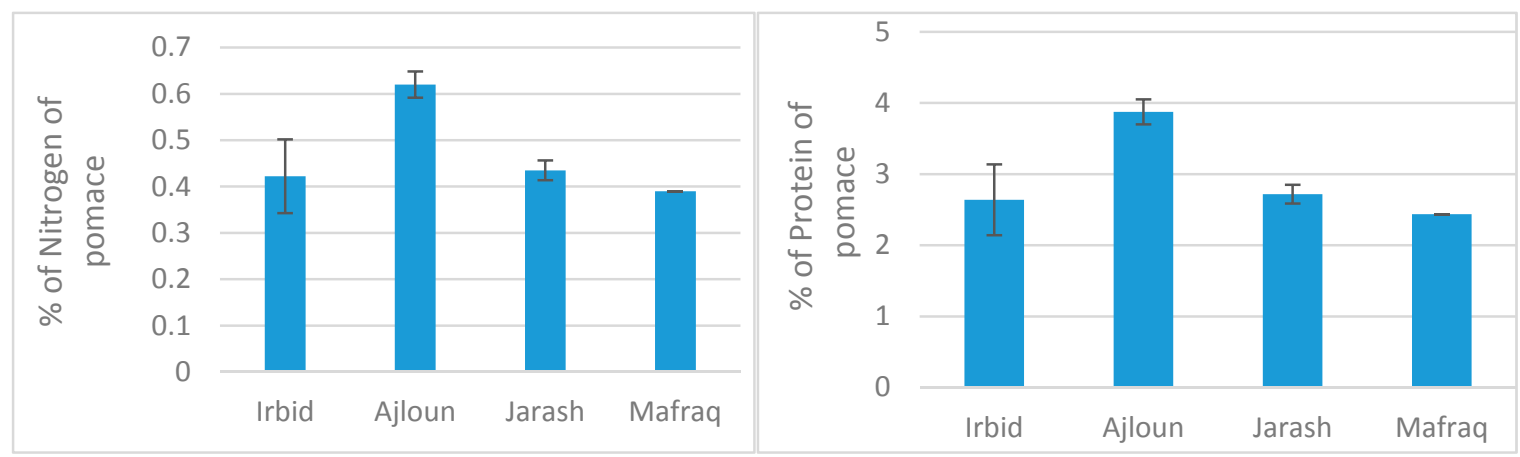

Figure 2. The percentage of nitrogen content and protein content of the olive pomace (different location)

In the current study, the percentage of total nitrogen (TN) was calculated according to Kjeldahl method and results indicated that Ajloun olive pomace contained high amounts of TN compared to the other locations, with a value $0.62 \pm 0.02$, while the lowest concentration was Mafraq samples with a value $0.39 \pm 0.00$., these findings were similar to the previous study, on the other hand, Irbid and Jarash had a moderate amount of total nitrogen with moderate values. As mentioned before [Figure 2], the total nitrogen measurement were quiet different, suggesting that the composition of environments and their percentage may be responsible for the nutrients composition of modifications [François, et. al., 2008]. Moreover, these differences were accounted. Interaction between TN and lignocellulos fraction represented by the fiber, may be responsible for the low amount and the significant difference between samples that collected may reflect the effect of change of temperature range between different seasons and the amount of rain in the rainy seasons.

Also, the processes of extraction may have an effect on the protein percentage because of the biological processes during extraction, but not the extraction process itself [Diacono, et. al., 2012].

\section{Fatty acid}

Table 1 shows the fatty acids profile distribution that shows a clear bulk for C 18:1 (oleic acid) residue in all locations and the values with wide range between $59.03 \%$ from Jarash to $63.81 \%$ Mafraq. C 16:0 (palmitic acid) values was widely ranged from $15.84 \%$ in Ajloun to $20.80 \%$ in Mafraq. And very little amounts of $C$ 14:0 (Myristic acid) in all locations with the highest percentage $(0.15 \%)$ in Jarash olive press and the lowest was $0.03 \%$ Mafraq. other fatty acids percentage were quantified also.

Table 1. The means values of fatty acid profile in olive pomace samples.

\begin{tabular}{ccccc}
\hline & Irbid & Ajloun & Jarash & Mafraq \\
\hline C 14:0 & 0.04 & 0.14 & 0.15 & 0.03 \\
\hline
\end{tabular}




$\begin{array}{lllll}\text { C 16:0 } & 19.07 & 15.84 & 20.02 & 20.80 \\ \text { C 16:1 } & 0.71 & 0.77 & 0.78 & 0.81 \\ \text { C 17:0 } & 0.14 & 2.47 & 0.19 & 0.06 \\ \text { C 17:1 } & 0.12 & 0.11 & 0.18 & 0.06 \\ \text { C 18:0 } & 3.74 & 3.70 & 3.70 & 2.69 \\ \text { C 18:1 } & 62.64 & 62.99 & 59.03 & 63.81 \\ \text { C 18:2 } & 11.52 & 11.52 & 12.33 & 10.43 \\ \text { C 18:3 } & 0.69 & 0.87 & 0.67 & 0.67 \\ \text { C 20:0 } & 0.49 & 0.57 & 0.46 & 0.21 \\ \text { C 20:1 } & 0.26 & 0.27 & 0.25 & 0.22 \\ \text { C 22:0 } & 0.16 & 0.15 & 0.11 & 0.14 \\ \text { C 24:0 } & 0.40 & 0.63 & 2.14 & 0.06\end{array}$

The results revealed that 3 fatty acids had the highest percentage, one saturated C 16:0 (Palmitic acid) and one Monounsaturated C 18:1 (oleic acid) and the other one Polyunsaturated fatty acid C 18:2 (Linoleic acid), Irbid had values for previous fatty acids $(19.07 \pm 2.55),(62.63 \pm 2.39),(11.51 \pm 1.55)$ respectively, Ajloun values was $(15.84 \pm 3.37),(62.99 \pm 2.12),(11.52 \pm 2.57)$ respectively, and for Jarash it was $(20.02 \pm 2.85)(59.03 \pm 5.61),(12.32 \pm 1.19)$ respectively and Mafraq was $(20.8 \pm 0.0),(63.81 \pm 0.0)$, $(10.43 \pm 0.0)$ respectively (Fig 3a,b). C 18:0 had low percentage ranged between 0.21 for Mafraq to 0.57 \pm 0.19 for Ajloun and Irbid, Jarash were $0.49 \pm 0.07,0.45 \pm 0.17$ respectively, while the remaining percentage in all locations of fatty acids was very low. Monounsaturated fatty acids have great importance because of their nutritional implication and effect on the oxidative stability of oils. This study found that the pomace oleic acid monounsaturated (C 18:1) is an important constituent part of the pomace content with percentage between $(59.03 \pm 5.61)$ to $(63.81 \pm 0.00)$ (table 1$)$. This result agrees with the other findings studies [Clemente, et. al., 1997].
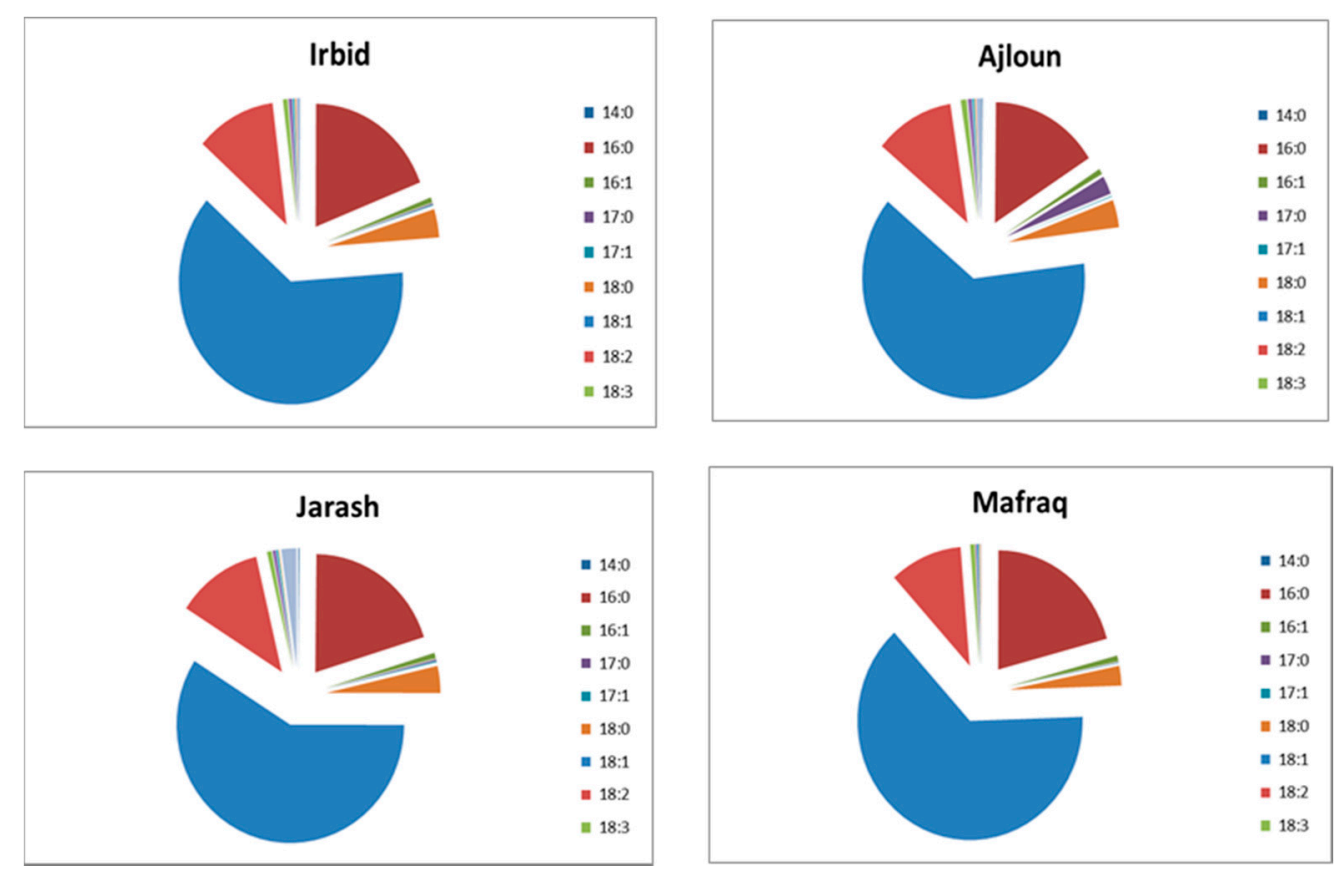

Figure 3a. Percentage of all fatty acids in each area. 
6 of 8

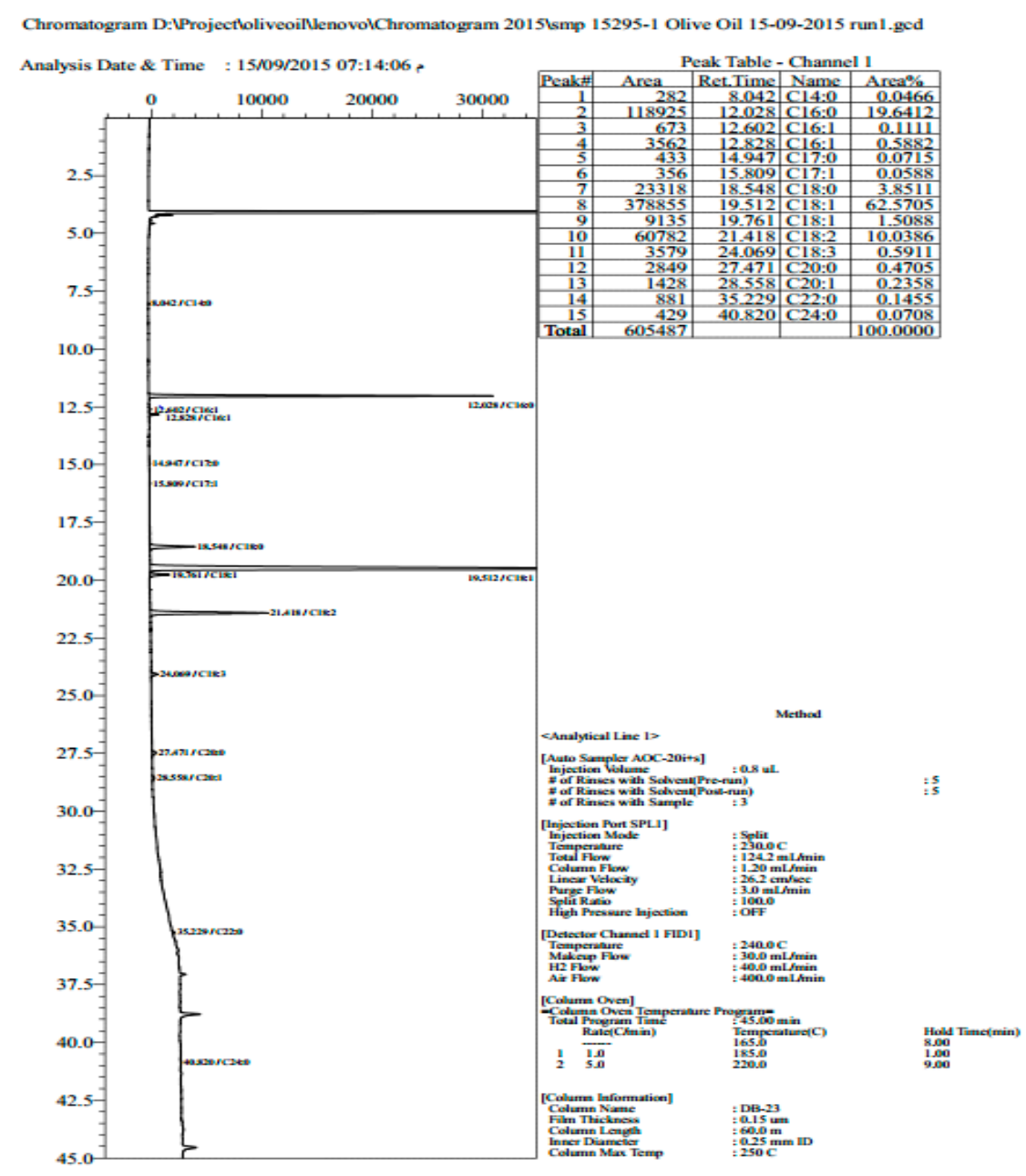

Figure 3b Chromatography of fatty acid analysis for Kfarat-Press (Irbid)

The distribution of relative amounts of saturated vs unsaturated fatty acids shown in figure 4. The overall unsaturated fatty acid /saturated fatty acid for all locations was (76\%: 24\%), (77\%: 23\%), (73\%: 27\%) and (73\%: 24\%) for Irbid, Ajloun, Jarash, Mafraq respectively. 
Irbid

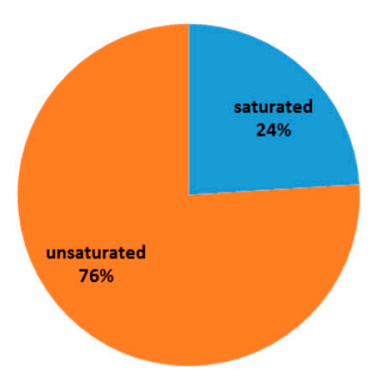

Jarash

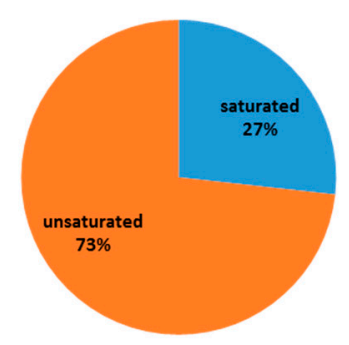

Ajloun

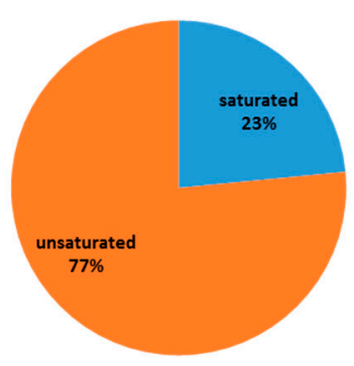

Mafraq

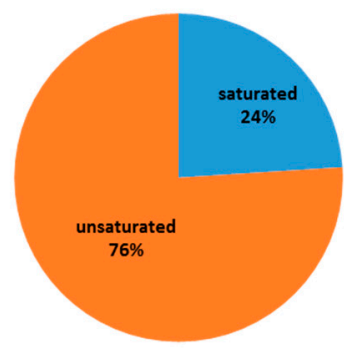

Figure 4. Saturated and unsaturated percentage of fatty acids in different area.

Strong linear positive correlation coefficients $(\mathrm{P} \leq 0.05)$ in Table 2 were found between $\mathrm{C} 14: 0$ C18:2 ( $\mathrm{r}=0.781), \mathrm{C} 14: 0-\mathrm{C} 24: 0(\mathrm{r}=0.776), \mathrm{C} 17: 0-\mathrm{C} 18: 3(\mathrm{r}=0.994), \mathrm{C} 17: 1-\mathrm{C} 18: 0(\mathrm{r}=0.756)$, and C17:1$\mathrm{C} 18: 2(\mathrm{r}=0.973)$, and $\mathrm{C} 17: 1-\mathrm{C} 24: 0(\mathrm{r}=0.922)$, and C18:0-C18:2 ( $\mathrm{r}=0.86)$, and C18:0-C20:0 $(\mathrm{r}=0.717)$, and C18:1-C22:0 ( $\mathrm{r}=0.815)$, and C18:2-C20:0 ( $\mathrm{r}=0.717)$, and C18:2-C24:0 ( $\mathrm{r}=0.881)$, and C18:2-C20:0 $(\mathrm{r}=0.717)$, and C20:0-C20:1 ( $\mathrm{r}=0.997)$.

Conversely, strong negative correlation coefficients were found between C16:0-C17:0 ( $\mathrm{r}=$ 0.953), C16:0-C18:3 ( $\mathrm{r}=-0.971)$, and C16:0-C20:0 ( $\mathrm{r}=-0.794)$, and C16:0-C20:1 ( $\mathrm{r}=-0.785)$, and C16:1$\mathrm{C} 18: 0(\mathrm{r}=-0.721)$, and C17:1-C18:1 ( $\mathrm{r}=-0.964)$, and C18:1-C18:2 (r=-0.887), and C18:1-C24:0 (r= $0.986)$, and C22:0-C24:0 ( $\mathrm{r}=-0.843)$ table 2.

Table 2. Pearson correlation test for fatty acids.

\begin{tabular}{|c|c|c|c|c|c|c|c|c|c|c|c|c|c|}
\hline & C 14:0 & C $16: 0$ & C 16:1 & C $17: 0$ & C $17: 1$ & C 18:0 & C $18: 1$ & C $18: 2$ & C $18: 3$ & C 20:0 & C $20: 1$ & C $22: 0$ & C 24:0 \\
\hline C 14:0 & 1 & & & & & & & & & & & & \\
\hline C 16:0 & -0.507 & 1 & & & & & & & & & & & \\
\hline C $16: 1$ & 0.100 & 0.296 & 1 & & & & & & & & & & \\
\hline C $17: 0$ & 0.553 & -0.953 & 0.006 & 1 & & & & & & & & & \\
\hline C $17: 1$ & 0.678 & 0.000 & -0.333 & -0.116 & * 1 & & & & & & & & \\
\hline C 18:0 & 0.617 & -0.560 & -0.721 & 0.351 & 0.756 & 1 & & & & & & & \\
\hline C $18: 1$ & -0.671 & -0.204 & 0.030 & 0.235 & -0.946 & -0.517 & 1 & & & & & & \\
\hline C $18: 2$ & ${ }^{*} 0.781$ & -0.228 & -0.382 & 0.107 & ${ }^{*} 0.973$ & *0.86 & -0.877 & 1 & & & & & \\
\hline C $18: 3$ & 0.482 & -0.971 & -0.073 & *0.994 & -0.157 & 0.363 & 0.302 & 0.070 & 1 & & & & \\
\hline C 20:0 & 0.645 & -0.794 & -0.644 & 0.623 & 0.553 & ${ }^{*} 0.947$ & -0.298 & ${ }^{*} 0.717$ & 0.639 & 1 & & & \\
\hline C $20: 1$ & 0.599 & -0.785 & -0.690 & 0.599 & 0.536 & ${ }^{*} 0.949$ & -0.269 & 0.697 & 0.621 & ${ }^{*} 0.997$ & 1 & & \\
\hline C 22:0 & -0.566 & -0.405 & -0.550 & 0.259 & -0.589 & 0.017 & ${ }^{*} 0.815$ & -0.489 & 0.359 & 0.171 & 0.220 & 1 & \\
\hline C 24:0 & ${ }^{*} 0.776$ & 0.094 & 0.055 & -0.092 & ${ }^{*} 0.922$ & 0.519 & -0.986 & ${ }^{*} 0.881$ & -0.169 & 0.342 & 0.305 & -0.843 & 1 \\
\hline
\end{tabular}


The oil quality had well known for oleic acid C 18:1 / Linoleic acid C 18:2 Ratio, the results showed that the ratio for each location (Irbid, Ajloun, Jarash, and Mafraq) were $5.43 \pm 1.53,5.46 \pm$ $0.82,4.78 \pm 1.3$ and $6.11 \pm 0.0$ respectively (table 3). There was no significant difference in olive pomace oil quality.

Table 3. C 18:1 / C18:2 Coefficient of variation.

\begin{tabular}{cccccc}
\hline & C18:1 (\%) & C18:2 (\%) & C18:1/C18:2 & STDV & C.V\% \\
\hline Irbid & 62.64 & 11.52 & 5.44 & 1.54 & 27.77 \\
Ajloun & 62.99 & 11.52 & 5.47 & 0.82 & 14.73 \\
Jarash & 59.03 & 12.33 & 4.79 & 1.35 & 28.24 \\
Mafraq & 63.81 & 10.43 & 6.12 & 0 & 0 \\
\hline
\end{tabular}

Oleic acid/linoleic acid ratio and monounsaturated fatty acids/polyunsaturated fatty acids (MUFAs/PUFAs) ratios (table 3), showed variation. The analysis of variance (CV\%) revealed a significant differences between locations which agree with the study done by (Zarrouk, et. al., 2009). The results of this study showed that the levels of gamma linoleic acid C 18:3 was generally below $1 \%$, but other studies that regard to the olive oil fatty acids profile showed different results [Stefanoudaki,, et. al., 1999], So according to the International Olive Council form (IOOC, 2008) for the total linolenic acid is not specific for many olive varieties. El Antari et al., (2003) and his colleagues found that the levels of C18:3 is more than 1\% in Moroccan oils [Stefanoudaki, et al., 1999]. While Ravetti (2000) reported the levels up to 1.42\% C18:3 in Argentinean oils. Similar results were shown in New Zealand [Meehan, 2001] with up to 1.5\% and in Lecce (Italy), C18:3 levels in a series of olive samples ranged from $1.1 \%$ to $1.4 \%$ [Dettori and Russo, 1993]. These variations were attributed variation to seasonal differences, particularly water availability and temperature [Paz Romero et al., 2003]. The previous work suggesting that the percentage of C18:1 is negatively correlated with the relative humidity of the atmosphere [Zarrouk, et. al., 2009]. Sioriki, et al., 2016 found that the fish nourished with OP might be suggestion that these stuffs are possible to be the important polar phospholipids that have the capacity to be in vitro Platelet Activating Factor (PAF) inhibitors, i.e. inhibit the development of atherosclerotic plaques in blood vessels. While other study indicated that the total lipids of gilthead sea bream nourished with olive pomace diet limited statistically reduced concentrations of fatty acids, whereas presented the strongest biological activity against platelet aggregation induced by Platelet Activating Factor. These information designate that olive pomace is used as a fractional additional of fish oil in fish feedstuff serving its cardio protective wealth [Nasopoulou et al, 2011].

This study did not show significant difference in C 18:1 and that may be due to very similar geographical area with same atmosphere and humidity conditions. The results of this study prove that the fatty acid composition have a significant discriminating power even with in close geographical areas.

This work allowed to describe the main chemical characteristics of olive pomace collected from the northern part of Jordan that showed higher unsaturated fatty acids composition compared to saturated fatty acids, C 18:1 percentage had a negative correlation with humidity in atmosphere which positively affects oil stability. Also, high concentration of total nitrogen sample was due to 
change in climate, those with cold and rainy climate show higher concentrations. In a future work, further exploration for olive pomace oil stability and pomace chemical characteristics. And study the all fractions of lipid content of OP (polar and neutral) and compere the values with published values to evaluate the importance of these fractions in all aspects.

Acknowledgements

The authors thank all the people who help to do this work. A grant from The Hashemite University is acknowledged.

\section{References}

1. Alburquerque, J. A., Gonzalvez, J., Garcia, D., \&Cegarra, J. Agrochemical characterisation of “'alperujo”, a solid by-product of the two-phase centrifugation method for olive oil extraction.Bioresources Technology,91(2), 195200 (2004).

2. Brunetti, G., Plaza, C., \&Senesi, N. Olive pomace amendment in Mediterranean conditions: effect on soilandhumic acid properties and wheat (Triticumturgidum L.) yield. Journal of Agricultural and Food Chemistry, 53(17), 6730-6737 (2005).

3. Cardoso, S. M., Silva, A. M. S., \& Coimbra, M. A. Structural characterisation of the olive pomace pecticpolysaccharide arabinan side chains. Carbohydrate Research, 337(10), 917-924 (2002).

4. Charles, H., Godfray, J., Beddington, J. R., Crute, I. R., Haddad, L., Lawrence, D.,Toulmin, M. FoodSecurity: The Challenge of Feeding 9 Billion People. Science, 327(5967), 812-818 (2010).

5. Clemente A, Sánchez-Vioque R, Vioque J, Bautista J, Millan F. "Chemical Composition Of Extracted Dried Olive Pomaces Containing Two And Three Phases". Food Biotechnology 11.3 (1997): 273-291.

6. Dettori, S., \& Russo, G. (1993). Influencia del cultivar y del régimen hídrico sobre el volulmen y la calidad del aceite de oliva. Olivae: revista oficial del Consejo Oleícola Internacional, (49), 36-43.

7. Di Giovacchino, L. Olive harvesting and olive oil extraction. In D. Boskou (Ed.), Olive Oil: Chemistry and Technology (pp. 12-51). Illinois: AOCS Press Champaign (1996).

8. Diacono, M., Ferri, D., Ciaccia, C., Tittarelli, F., Ceglie, F., Verrastro, V., Ventrella, D., Vitti, C. and Montemurro, F "Bioassays And Application Of Olive Pomace Compost On Emmer: Effects On Yield And Soil Properties In Organic Farming". ActaAgriculturaeScandinavica, Section B - Soil \& Plant Science (2012): 1-9.

9. El Antari A, El Moudni A, Ajana H, Cert A. 2003. Lipid composition of two fruits parts (flesh and kernel) of six varieties of olive tree cultivated in Morocco. Olivae 28, 20-28.

10. El Nockrashy, A.S., K.D. Mukherjee, and H.K. Mangold, Rapeseed Protein Isolates by Countercurrent Extraction and Isoelectric Precipitation, journal of Agricultural and Food Chemistry. 25:193-197 (1977).

11. Fedeli, E., Technology of Oil Production and Conservation, in Enciclopedia Mundial del Olivo, edited by The International Oleic Council, Plaza y Janes, Barcelona, pp. 251-291 (1996).

12. François M, Tomé D, and Mirand P. "Converting Nitrogen Into Protein-Beyond 6.25 And Jones' Factors". Critical Reviews in Food Science and Nutrition 48.2 (2008): 177-184.

13. Grasser, L. A., Fadel, J. G., Garnett, I., \&Depeters, E. Quantity and economic importance of 9 selectedbyproducts used in California dairy rations. Journal of Dairy Science, 78(4), 962-971 (1995)

14. https://www.AOAC International 
15. Kumar, R., and M. Singh, Tannins: Their Adverse Role in Ruminant Nutrition, Journal of Agricultural and Food Chemistry. 32:447-453 (1984).

16. Lahl, W.J., and S.D. Braun, Enzymatic Production of Protein Hydrolysates for Food Use, Food Techchnology. 48:68-71 (1994)

17. Meehan, C. K. (2001). The quality of New Zealand olive oil. BhortSc (Hons) Thesis, Lincoln University, New Zealand.

18. Nasopoulou, C., Stamatakis, G., Demopoulos, C. A., \& Zabetakis, I. (2011). Effects of olive pomace and olive pomace oil on growth performance, fatty acid composition and cardio protective properties of gilthead sea bream (Sparus aurata) and sea bass (Dicentrarchus labrax). Food chemistry, 129(3), 1108-1113.

19. Nasopoulou, C., \& Zabetakis, I. (2013). Agricultural and aquacultural potential of olive pomace a review. Journal of Agricultural Science, 5(7), 116.

20. Official Journal of European Communities. Regulation EEC No 356/92 (1992).

21. Ravetti, L. M., Matías, A. C., Patumi, M., Rocchi, P., \& Fontanazza, G. (2000, September). CHARACTERIZATION OF VIRGIN OLIVE OILS FROM CATAMARCA AND LA RIOJA, ARGENTINA, GENERAL CHARACTERISTICS. In IV International Symposium on Olive Growing 586 (pp. 603-606).

22. Roig, A., Cayuela, M. L., \& Sánchez-Monedero, M. A. An overview on olive mill wastes and their valorization methods. Waste Management, 26(9), 960-969 (2006).

23. Romero, M. P., Tovar, M. J., Ramo, T., \& Motilva, M. J. (2003). Effect of crop season on the composition of virgin olive oil with protected designation of origin "Les Garrigues". Journal of the American Oil Chemists' Society, 80(5), 423-430.

24. Saeed, M., and M. Cheryan, Sunflower Protein Concentrates and Isolates Low in Polyphenols and Phytate, Journal of Food Science. 53:1127-1131 (1988).

25. Sansoucy, R. Olive by-products for animal feed.FAO Anim. Production Health, 43, FAO, Rome (1985).

26. Sioriki, E., Smith, T. K., Demopoulos, C. A., \& Zabetakis, I. (2016). Structure and cardioprotective activities of polar lipids of olive pomace, olive pomace-enriched fish feed and olive pomace fed gilthead sea bream (Sparus aurata). Food Research International, 83, 143-151.

27. Stefanoudaki, E., Kotsifaki, F., and Koutsaftakis, A. "Classification Of Virgin Olive Oils Of The Two Major Cretan Cultivars Based On Their Fatty Acid Composition". Journal of the American Oil Chemists' Society 76.5 (1999): 623-626.

28. Valiente, C., E. Arrigoni, J.R. Corrales, R.M. Esteban, and R. Amadò, Composition of Dietary Fiber in Olive Cake. Amino Acids Associated with Insoluble, Soluble and Total Dietary Fiber, Grasas Aceites 46:98-102 (1995)

29. Vioque, J., R. Sánchez-Vioque, A. Clemente, J. Pedroche, J. Bautista, and F. Millán, Production and Characterization of an Extensive Rapeseed Protein Hydrolysate, Journal of American Oil Chemistry. 76:819$823(1999)$

30. Zarrouk W, Baccouri B, Taamalli W, Trigui A, Daoud D, Zarrouk M. "Oil Fatty Acid Composition Of Eighteen Mediterranean Olive Varieties Cultivated Under The Arid Conditions Of Boughrara (Southern Tunisia)". Grasas y Aceites 60.5 (2009): 500-508. 
31. (http://www.zaitt.com/about-zaitt).

(C) 2017 by the authors. Licensee Preprints, Basel, Switzerland. This article is an open access article distributed under the terms and conditions of the Creative Commons by Attribution (CC-BY) license (http://creativecommons.org/licenses/by/4.0/). 